\title{
Preliminary data on attractiveness of phenylacetaldehyde- based lures on economically important plant bug pests (Hemiptera: Miridae)
}

\author{
Szalárdi, T. ${ }^{1}$, Nagy, A. ${ }^{1}$, Oláh, F. ${ }^{1}$, Tóth, M. ${ }^{2} \&$ Koczor, S. ${ }^{2}$ \\ ${ }^{1}$ University of Debrecen Faculty of Agricultural and Food Sciences and Environmental Management, Institute of Plant Protection, \\ H-4002 Debrecen P.O.B. 400. Hungary, \\ ${ }^{2}$ Plant Protection Institute, Centre for Agricultural Research, Herman O. u. 15, Budapest H-1022, Hungary \\ Author for correspondence: nagyanti@agr.unideb.hu
}

\begin{abstract}
Summary: Several plant bug species (Miridae) are important pests of crops and vegetables, thus monitoring them is of essential importance for effective pest control. During the current, preliminary study synthetic plant volatile combinations were tested in field conditions in Hungary in alfalfa fields. Beside semiochemical baited traps, sweep-netting was also performed. In the experiments three plant bug species were found in higher numbers: Adelphocoris lineolatus, Lygus rugulipennis and L. pratensis. As a novel, interesting finding L. pratensis was attracted to phenylacetaldehyde baited traps. For all species, both males and females were trapped in all combinations. Sweep-netting and semiochemical baited traps showed different efficacy in case of the three species, as sweep-netting catches were highly biased for A. lineolatus, which indicates the higher efficacy of this method as compared to the tested semiochemical-baited traps. On the other hand, semiochemical baited showed better performance for $L$. rugulipennis and $L$. pratensis. For these species none of the tested combinations performed better than phenylacetaldehyde baited traps. The potential implication of results in view of monitoring are discussed.
\end{abstract}

Szalárdi, T., Nagy, A., Oláh, F., Tóth, M., Koczor, S. (2021): Preliminary data on attractiveness of phenylacetaldehyde-based lures on economically important plant bug pests (Hemiptera: Miridae). International Journal of Horticultural Science 27: 87-94. https://doi.org/10.31421/ijhs/27/2021/8259

Key words: integrated pest management, pest monitoring, trapping, volatiles

\section{Introduction}

Bugs (Hemiptera order, Heteroptera suborder) are one of the most important insect groups for agriculture considering both pest and beneficial species. Although Heteropterans have diverse life history traits, more than half of the about 40.000 known species are herbivorous (Vásárhelyi, 1996; Schuh \& Slater, 1995; Schaefer \& Panizzi, 2000) and some may cause significant economic losses due to their feeding and as vectors of different plant pathogens (e.g. Miller 1971). The Hungarian fauna consists of about 850 bug species (Kondorosy, 1999, 2005). About fifth of them are beneficial predators while others are mainly phytophagous including pestiferous species (Rácz, 1989). Pest species cause damages with their piercing and sucking mouthparts on both vegetative and generative parts of crops including vegetables and fruits.

Plant bugs (Miridae) is one of the economically most significant Heteroptera families primarily due to dangerous pests and also to beneficial species amongst them (e.g. Braimah et al., 1982; Cassis \& Schuh, 2012). Plant bugs may cause severe damage both in arable (e.g. Lu et al., 2010) and horticultural crops (e.g. Jay et al., 2004). In horticulture especially potato and strawberry are damaged by Miridae species. According to Easterbrook (2000) Lygus rugulipennis probably is the major cause of fruit malformation in late-season strawberry in the UK where it can mainly be a horticultural pest. In Hungary Lygus pratensis, L. rugulipennis, $L$. gemellatus, Poeciloscytus vulneratus and Adelphocoris lineolatus are more common and even abundant Miridae species cause damage mainly on pulses. Miridae pests have outstanding importance also in sunflower, cucumber, sweet corn and green pea production where they can cause damage directly with feeding and transmission of different pathogens. They often invade from nearby grasslands, alfalfa fields, and even mowed alfalfa fields and harvested grains where they can be abundant. These pests generally have 2 generations per year but there are species with 1 and 3 generations too. Most species overwinter as eggs and/or adults (Marcali, 2019; Hodossi et al., 2010). The control of mirid pests is mainly based on insecticides. The detection and monitoring of pest population dynamics are crucial for increasing efficacy of treatments and decreasing pesticide use (e.g. Witzgall et al., 2010).

Plant bugs can be sampled by transect counts, but this method is not quite efficient and robust due to the small size and large vagility of species (Rácz \& Bernáth, 1993). Sweepnet is an effective and easy to use tool for collecting plant bugs, but it is greatly affected by the structure of vegetation and other factors e.g. temperature, daily activity of different species and even the person of the sampler. Beyond that in some cultures sweep-net may harm plants (Rácz \& Bernáth, 1993; Varis, 1995; Fauvel, 1999). As passive sampling methods we can use light or colour traps to collect plant bugs. For instance, population dynamics of Lygus rugulipennis was studied by light-trap catches (Benedek et al., 1970), and by blue and 
yellow sticky traps as well (Holopainen, 2001). However, Pansa et al. (2008) could not confirm the effectiveness of blue and yellow colour traps, furthermore, Jay et al. (2004) suggested the use of white sticky traps in strawberry fields.

Traps baited with semiochemicals may provide a simple and efficient alternative tool for catching Miridae species through a wide variety of crops and also in horticulture. In case of some plant bug species presence of sex pheromones has been known for a long time (e.g. Scales, 1968; Strong et al., 1970; Smith et al., 1994; Scott \& Snodgrass, 2000) and for some species they are used in monitoring (McBrien et al., 1996). Nevertheless, sex pheromones attract only male plant bugs, thus semiochemicals attractive to both sexes could yield advantages from practical aspects.

Reports are available on laboratory and field experiments on allelochemicals attractive to both sexes of plant bugs (e.g. Blackmer et al., 2004; Frati et al., 2008; Fujii et al., 2010). For instance, attractiveness of phenylacetaldehyde for the Nearctic Lygus lineolaris was detected by Cantelo \& Jacobson (1979), but Blackmer \& Byers (2009) could not confirm their results. In laboratory experiments of Frati et al. (2008) Lygus rugulipennis was attracted by the fragrance of their host plant Vicia faba. At the same time the host plant positively affected pheromone production of females and the feeding of the pest modified the composition of host plant fragrance (Frati et al., 2009). In field experiments conducted in Hungary Koczor et al. (2012) found attraction of L. rugulipennis and A. lineolatus to phenylacetaldehyde and $(E)$-cinnamaldehyde. Recently Xiu et al. (2019) reported activity of further plant volatiles in EasternAsian populations of three Adelphocoris species. Our knowledge on host plant - pest interactions is insufficient but this topic may provide further perspectives in monitoring and even in improvement of management practices against Miridae pests as we can see this in case of other pest taxa e.g. Lepidoptera (Tóth et al., 2016, 2017, 2019a; Szanyi et al., 2017) Coleoptera (Tóth et al., 2019b) and Diptera (Katona et al., 2020).

In the present study we focused on L. rugulipennis and A. lineolatus. The studied plant bug species have wide host plant range, and L. rugulipennis is thought to be among the most polyphagous species in Europe (Holopainen \& Varis, 1991). In such polyphagous species which feed on several plant species, with possibly highly variable odour profiles, the number of compounds of potential importance in foraging may be remarkably high. Electroantennographic screenings is a possible method to do a preliminary selection between volatiles, however, as it was found for example in case of $L$. rugulipennis and A. lineolatus higher EAG responses do not warrant for more pronounced behavioural response (Koczor et al., 2012). Thus, in the course of the present, preliminary study we used another approach, that is, to screen combinations of common plant originated synthetic compounds for their effect in field conditions. Due to the polyphagous nature of these species, for the screenings we chose common plant volatiles, which have been identified from multiple plant families (e.g. Knudsen et al., 2006). We hypothesised that the number of compounds potentially eliciting remarkable behavioural responses are limited, and that compounds not eliciting such responses may possibly have lower effect on catches (for instance by masking), thus, we tested combinations of these compounds. In the first field test we evaluated ternary combinations of plant volatiles in combination with phenylacetaldehyde baits for potential synergistic or antagonistic effects while in another experiment the addition of the ternary blend showing possible activity in the first experiment and of its single components to phenylacetaldehyde was studied.

\section{Materials and methods}

\section{Preparation of baits}

For the experiments, synthetic compounds ( $\geq 95 \%$ chemical purity as per the manufacturer) were obtained from SigmaAldrich Kft. (Budapest, Hungary). Baits were prepared as follows: compounds were loaded onto a $1 \mathrm{~cm}$ piece of dental roll (Celluron ${ }^{\circledR}$, Paul Hartmann AG, Heidenheim, Germany), which was put into a polyethylene bag $(\mathrm{ca} 1.0 \times 1.5 \mathrm{~cm})$ made of $0.02 \mathrm{~mm}$ linear polyethylene foil (FS471-072, Phoenixplast BT, Pécs, Hungary). The load of individual compounds was kept at $100 \mathrm{mg}$ per compound. Phenylacetaldehyde was loaded in separate baits. The dispensers were heat sealed and attached to $8 \times 1 \mathrm{~cm}$ plastic handles for easy handling when assembling the traps. Dispensers were wrapped singly in pieces of aluminium foil and stored at $-18{ }^{\circ} \mathrm{C}$ until used.

\section{Field tests}

The field tests were carried out in the surroundings of Fürjes village (Békés County, Southeast Hungary) and Cegléd (Pest county, Central Hungary). For the experiments CSALOMON $^{\circledR}$ VARL funnel traps were used as these were found to be suitable for catching plant bugs (Koczor et al., 2012). Traps were placed along the edge of alfalfa fields on ground level at 8-10 meters distance. As a rule, based on previous experience baits were changed after 3-4 weeks. To avoid positional effects, positions of traps were changed regularly. In the traps VAPORTAPE® II pesticide strips (HERCON $\AA ;$ 2,2-dichlorvinyl-dimethyl phosphate 10.0\%) were used as killing agent. Samples of insects caught were stored in paper bags at $-20{ }^{\circ} \mathrm{C}$ till sorting and identification. Identification of Lygus and Adelphocoris species were made based on works of Wagner (1952) and Schwartz and Foottit (1998).

\section{The details of single experiments}

Experiment 1: The experiment was run from July 4 to October 1, 2016 near Fürjes (GPS: $46^{\circ} 40^{\prime} \mathrm{N} ; 2^{\circ} 01^{\prime} \mathrm{E}$ ), in complete block design, with 5 blocks (with 30 traps in total). Trap positions were rotated weekly. Treatments included:

- phenylacetaldehyde bait only

- phenylacetaldehyde bait + blend ' $A$ ' (isosafrole + anisylacetone +2 -phenylethanol)

- phenylacetaldehyde bait + blend 'B' (geraniol + nonanal + benzyl-acetate)

- phenylacetaldehyde bait + blend ' $C$ ' $((E)$-anethole $+(E)-2$ hexenal $+(Z)$-3-hexenol)

- phenylacetaldehyde bait + blend 'D' $((E)$-2-hexenol + betaionone + 1-nonanol)

- unbaited control

Experiment 2: The experiment was run from July 10 to September 14, 2017 near Cegléd (GPS: 47 $15^{\prime} \mathrm{N}$; 1946’ E), in randomized complete block design, with 4 blocks (with 24 traps in total). Trap positions were rotated biweekly. Treatments included:

- phenylacetaldehyde bait only 
- phenylacetaldehyde bait +2 -phenylethanol bait

- phenylacetaldehyde bait + anisyl acetone bait

- phenylacetaldehyde bait + isosafrole bait

- phenylacetaldehyde bait + blend ' $A$ ' (isosafrole + anisylacetone +2 -phenylethanol)

- unbaited control

\section{Sweep-net samples}

In 2016 additionally sweep-net samples were taken to characterize quantitative structure of Miridae assemblage of the studied alfalfa field by another, standard method. Three samples each with 100 sweeps (sum 300 sweeps/time) were taken four times during the study in $4^{\text {th }}$ and $21^{\text {st }}$ of August and $10^{\text {th }}$ and $25^{\text {th }}$ of September 2016. Sampled transects were parallel to field edge where the traps were set out.

\section{Data analysis}

Catch data were summed for weeks, and weeks with low catches accounting for less than $5 \%$ of total catches of the respective species were excluded from the statistical analysis. Data were tested for normality by Shapiro-Wilk tests. Since none of the experimental data were found to be normally distributed, nonparametric tests were used. Data were analyzed by Kruskal-Wallis test, and differences between treatments were evaluated by pairwise Wilcoxon test with BenjaminiHochberg correction. Statistical procedures were conducted using the software R (R Core Team 2016).

\section{Results}

Beside A. lineolatus and L. rugulipennis, another mirid, $L$. pratensis was caught in sufficient numbers for further analysis. Other plant bugs were found scarcely and were only represented by a few individuals. Among these only Lygus and Adelphocoris spp. were determined to species, these included L. gemellatus, A. seticornis and A. quadripunctatus.

\section{Catching data of Adelphocoris lineolatus}

In Experiment 1 relatively few A. lineolatus were caught. Only the treatment including phenylacetaldehyde bait and the ternary bait containing isosafrole, anisylacetone and 2phenylethanol (coded as blend 'A') caught significantly more individuals than unbaited control (Figure 1). Both male and female individuals were caught (Table 1).

In Experiment 2 in total each baited treatment caught more individuals than unbaited traps, however these differences were not statistically significant (Figure 2), both male and female individuals were caught.

\section{Catching data of Lygus rugulipennis}

In Experiment 1, all baited treatments caught more individuals than unbaited control. Among the different combinations none attracted more individuals than phenylacetaldehyde alone, furthermore the treatments containing the ternary combinations containing geraniol, nonanal and benzyl-acetate (coded blend 'B') and (E)-2hexenol, beta-ionone and 1-nonanol (coded blend 'D') caught fewer individuals than phenylacetaldehyde alone (Figure 1). Both male and female individuals were caught (Table 1).
In Experiment 2, all baited treatments caught more individuals than unbaited control. None of the combinations attracted more individuals than phenylacetaldehyde alone, no significant differences were found among catches of baited treatments (Figure 2).

\section{Catching data of Lygus pratensis}

In Experiment 1, traps baited with phenylacetaldehyde alone attracted more individuals than unbaited control. None of the combinations attracted more individuals than phenylacetaldehyde alone, furthermore, catches of the ternary combinations containing geraniol, nonanal and benzyl-acetate (coded blend 'B') and (E)-2-hexenol, beta-ionone and 1nonanol (coded blend 'D') caught significantly fewer $L$. pratensis than phenylacetaldehyde alone, catches of these treatments did not differ from unbaited control (Figure 1). Both male and female individuals were caught (Table 1).

In Experiment 2, all baited treatments attracted more individuals than unbaited control. Irrespective of combinations, catches of baited treatments did not differ significantly (Figure 2).

\section{Sweep-net sampling}

Sweep-net catches were strongly biased for A. lineolatus, as L. rugulipennis and $L$. pratensis were caught in considerably lower numbers (Table 1). For all three species a large percentage of individuals caught were females (Table 1).

\section{Discussion}

Semiochemical baited traps may provide a valuable, easy to use method for monitoring pests, serving with continuous data on local abundance and population dynamics. From the practical view baits attractive to both sexes may have advantages as information on female population dynamics may offer more valuable information on future pest abundances than information on one sex only (as frequently seen in pheromone baited traps).

In the current study, as an interesting, novel finding, both males and females of $L$. pratensis were attracted to phenylacetaldehyde baited traps. We did not find former published data on it thus this is the first report on field attraction of the species to plant volatiles. Previously the sex pheromone composition of the species has been published (Fountain et al., 2014), however, the pheromone is only attractive to males, thus, phenylacetaldehyde baited traps may offer prospects for monitoring both sexes. Among the tested combinations, none increased attraction of $L$. pratensis to phenylacetaldehyde significantly, however, there were two combinations with significantly lower catches, these may be of interest in search for potentially repellent compounds in future studies.

For L. rugulipennis the results confirmed previous findings on attraction of the species to phenylacetaldehyde (Koczor et al., 2012). When testing ternary combinations, the tendencies were very similar to those of $L$. pratensis, that is none of the combinations increased attraction to phenylacetaldehyde, however the same two combinations decreased attraction. Further research on these combinations may bring novel, interesting results on the chemical ecology of host choice of these plant bug species. 

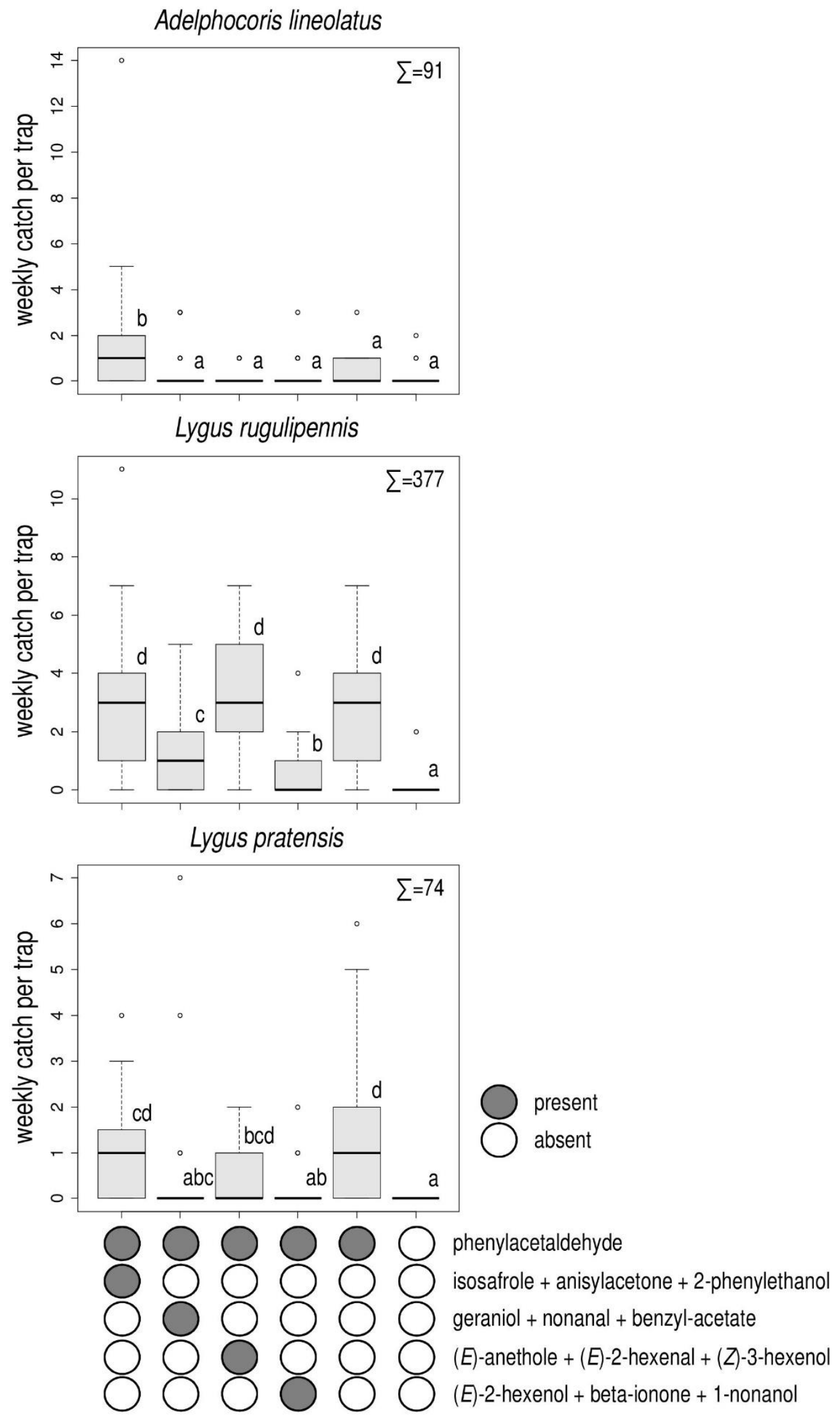

Figure 1. Weekly catches of Adelphocoris lineolatus, Lygus rugulipennis and L. pratensis in phenylacetaldehyde baited traps alone, in combination with ternary blends and in unbaited traps (Experiment 1). (Significance: Kruskal-Wallis test, pairwise comparisons by Wilcoxon test with Bonferroni correction at $\mathrm{p}=0.05$ ). ' $\sum$ ' indicates the total number of individuals caught of the respective species in the experiment. 

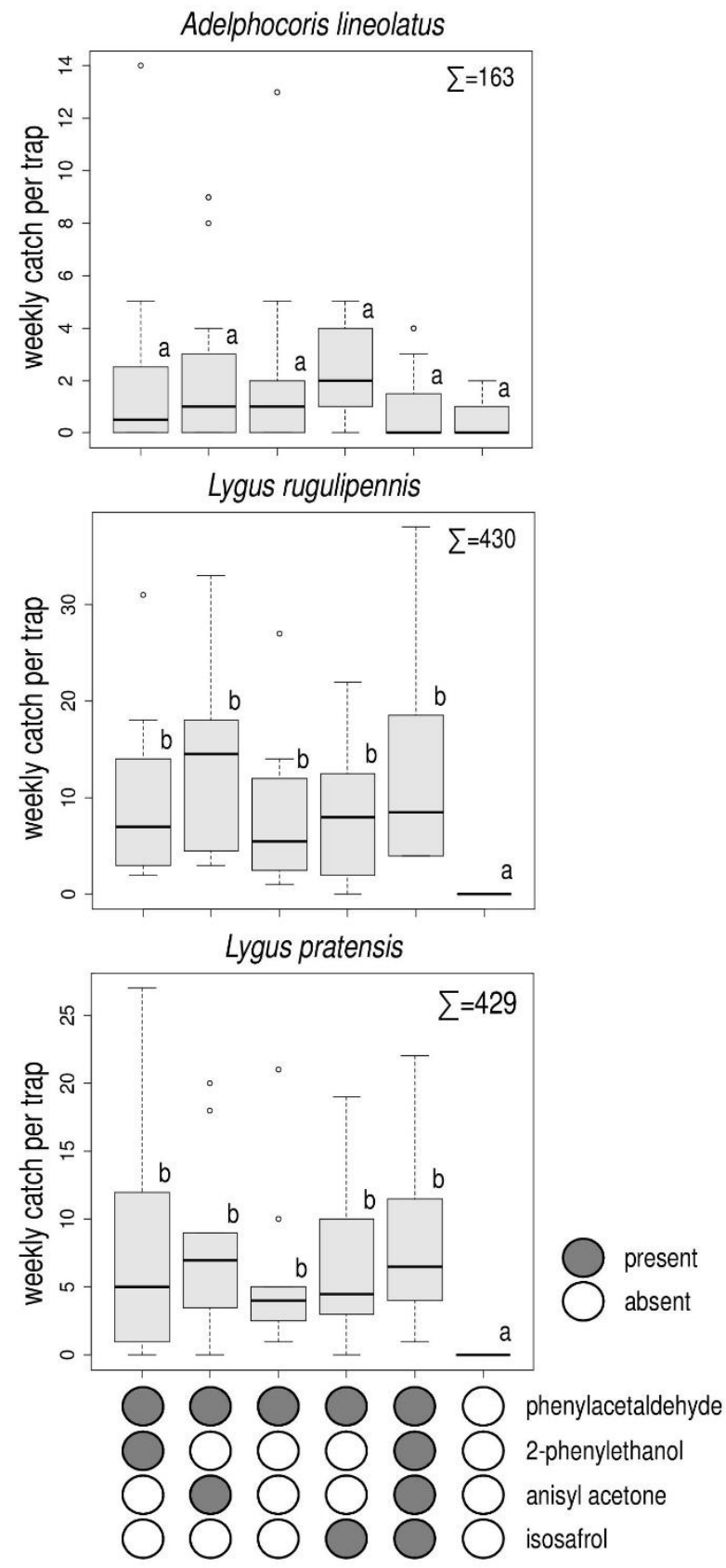

Figure 2. Weekly catches of Adelphocoris lineolatus, Lygus rugulipennis and L. pratensis in phenylacetaldehyde baited traps alone, in combination with either isosafrole, anisylacetone or 2-phenylethanol, in combination with their ternary blend and in unbaited traps (Experiment 2). (Significance: Kruskal-Wallis test, pairwise comparisons by Wilcoxon test with Bonferroni correction at $\mathrm{p}=0.05$ ). ' $\sum$ ' indicates the total number of individuals caught of the respective species in the experiment.

Table 1. Mean catch of Adelphocoris lineolatus, Lygus rugulipennis and Lygus pratensis in semiochemical baited traps (catch/trap) and sweep-net samples (catch/100 sweeps) and ratio of females in 2016 in Fürjes (Hungary), for composition of blends, please refer to the text.

\begin{tabular}{|c|c|c|c|c|c|c|}
\hline \multirow[t]{3}{*}{ Baits and methods } & \multicolumn{6}{|c|}{ Species } \\
\hline & \multicolumn{2}{|c|}{ A. lineolatus } & \multicolumn{2}{|c|}{ L. rugulipennis } & \multicolumn{2}{|c|}{ L. pratensis } \\
\hline & mean $\pm \mathrm{SE}$ & female $\%$ & mean $\pm \mathrm{SE}$ & female $\%$ & mean $\pm \mathrm{SE}$ & female $\%$ \\
\hline phenylacetaldehyde & $2.8 \pm 0.6$ & $55.0 \pm 22.9$ & $22.6 \pm 1.4$ & $52.9 \pm 7.0$ & $5.8 \pm 0.8$ & $42.4 \pm 14.5$ \\
\hline phenylacetaldehyde + blend 'A' & $11.8 \pm 4.6$ & $34.6 \pm 7.9$ & $25.0 \pm 2.1$ & $53.4 \pm 5.0$ & $5.8 \pm 1.0$ & $48.8 \pm 11.7$ \\
\hline phenylacetaldehyde + blend 'B' & $2.8 \pm 1.1$ & $41.7 \pm 14.4$ & $9.0 \pm 1.4$ & $55.4 \pm 11.0$ & $2.6 \pm 2.1$ & $45.5 \pm 29.2$ \\
\hline phenylacetaldehyde + blend 'C' & $1.4 \pm 0.7$ & $88.9 \pm 11.1$ & $27.0 \pm 3.6$ & $45.6 \pm 3.7$ & $3.4 \pm 0.7$ & $33.7 \pm 15.3$ \\
\hline phenylacetaldehyde + blend 'D' & $2.2 \pm 1.2$ & $40.0 \pm 20.0$ & $3.8 \pm 0.7$ & $51.0 \pm 14.4$ & $0.8 \pm 0.4$ & $16.7 \pm 16.7$ \\
\hline unbaited traps & $0.8 \pm 0.4$ & $16.7 \pm 16.7$ & $0.8 \pm 0.4$ & $16.7 \pm 16.7$ & $0.0 \pm 0.0$ & - \\
\hline sweep-netting & $19.3 \pm 4.6$ & $55.2 \pm 3.4$ & $6.3 \pm 0.9$ & $36.6 \pm 8.4$ & $1.1 \pm 0.4$ & $71.4 \pm 14.9$ \\
\hline
\end{tabular}


In the current study for A. lineolatus relatively few individuals were caught in semiochemical baited traps. Among the tested combinations, blend ' $A$ ' containing isosafrole, anisylacetone and 2-phenylethanol attracted more individuals than phenylacetaldehyde alone, thus Exp. 2. was set up. However, although baited treatments caught numerically more A. lineolatus, differences between treatments including unbaited traps were not statistically significant. Nevertheless, it is important to note that Exp. 2 was run with fewer replicates (4 blocks instead of 5), which might also affected statistical results. For this species attraction of adults of Eastern-Asian populations to some selected plant volatiles has been recently published (Xiu et al., 2019), further research on these compounds in Central European populations may be of interest in search for effective attractant combinations.

Trapping and sweep-netting are remarkably different sampling methods since sweep-netting provides information on a narrow time window along a transect, whereas baited traps provide information on a given location for a longer period of time (e.g. Stewart, 2002) thus, it is not obvious to make comparisons amongst them. Nevertheless, we believe this information may be useful, thus, in our study, as standard sampling efforts we calculated the catches for 100 sweeps and for one trap of the respective treatment.

In our experiments semiochemical-baited traps and sweepnetting showed remarkably different efficacy in case of the three species. Sweep-net catches were strongly biased for $A$. lineolatus, which indicates the high efficacy of this method for collecting this species. Sweep-netting clearly outperformed semiochemical baited traps, which indicates that the tested combinations should be further optimised, before considered for practical application, especially in cultures, where sweepnetting is a viable and applied method for monitoring.

On the other hand, semiochemical baited traps performed much better for L. rugulipennis and L. pratensis as compared to sweep-netting, which indicates that phenylacetaldehyde baited traps may offer a potential alternative for monitoring males and females of these species, especially in cultures, where sweepnetting is not favourable. Nevertheless it is important to emphasize that unlike semiochemical baited traps sweepnetting provides information on the abundance of the given species in a very short time window, thus, catches may be strongly biased depending on the actual abundance and activity of the respective species and even affected by actual weather conditions and the appliers' skills.

\section{Acknowledgements}

The research was financed by the Higher Education Institutional Excellence Programme (NKFIH-1150-6/2019) of the Ministry of Innovation and Technology in Hungary, within the framework of the 4th thematic programme of the University of Debrecen.

\section{References}

Benedek, P., Erdélyi, Cs., Jászai, V. E. (1970): Seasonal activity of heteropterous species injurious to lucerne and its relations to the integrated pest control of lucerne grown for seed. Acta Phytopathologica et Entomologica Hungarica 5: 81-93.

Blackmer, J. L., Byers, J. A. (2009): Lygus spp. (Heteroptera: Miridae) host-plant interactions with Lesquerella fendleri
(Brassicaceae), a new crop in the arid southwest. Environmental Entomology 38: 159-167. https://doi.org/10.1603/022.038.0120

Blackmer, J. L., Rodriguez-Saona, C., Byers, J. A., Shope, K. L., Smith, J. P. (2004): Behavioral response of Lygus hesperus to conspecifics and headspace volatiles of alfalfa in a Y-tube olfactometer. Journal of Chemical Ecology 30: 15471564. https://doi.org/10.1023/B:JOEC.0000042067.27698.30

Braimah, S. A., Kelton, L. A., Stewart, R. K. (1982): The predaceous and phytophagous plant bugs (Heteroptera: Miridae) found on apple trees in Québec. Le Naturaliste Canadien 109: 153-180.

Cantelo, W. W., Jacobson, M. (1979): Corn silk volatiles attract many species of moths. Journal of Environmental Science and Health part A 14: 695-707. https://doi.org/10.1080/10934527909374907

Cassis, G., Schuh, R. T. (2012): Systematics, biodiversity, biogeography, and host associations of the Miridae (Insecta: Hemiptera: Heteroptera: Cimicomorpha). Annual Review of Entomology 57: 377-404. https://doi.org/10.1146/annurevento-121510-133533

Easterbrook, M. A. (2000): Relationships between the occurrence of misshapen fruit on late-season strawberry in the United Kingdom and infestation by insects, particularly the European tarnished plant bug, Lygus rugulipennis. Entomologia Experimentalis et Applicata 96: 59-67. https://doi.org/10.1046/j.1570-7458.2000.00679.x

Fauvel, G. (1999): Diversity of Heteroptera in agroecosystems: role of sustainability and bioindication. Agriculture, Ecosystems and Environment 74: 275-303. https://doi.org/10.1016/S0167-8809(99)00039-0

Fountain, M., Jåstad, G., Hall, D., Douglas, P., Farman, D., Cross, J. (2014): Further studies on sex pheromones of female Lygus and related bugs: development of effective lures and investigation of species-specificity. Journal of Chemical Ecology 40: 71-83. https://doi.org/10.1007/s10886-013-0375-Z

Frati, F., Chamberlain, K., Birkett, M., Dufour, S., Mayon, P., Woodcock, C., Wadhams, L., Pickett, J., Salerno, G., Conti, E., Bin, F. (2009): Vicia faba - Lygus rugulipennis interactions: induced plant volatiles and sex pheromone enhancement. Journal of Chemical Ecology 35: 201-208. https://doi.org/10.1007/s10886-008-9572-6

Frati, F., Salerno, G., Conti, E., Bin, F. (2008): Role of the plant-conspecific complex in host location and intra-specific communication of Lygus rugulipennis. Physiological Entomology 33: 129-137. https://doi.org/10.1111/j.13653032.2008.00614.x

Fujii, T., Hori, M., Matsuda, K. (2010): Attractants for rice leaf bug, Trigonotylus caelestialium (Kirkaldy), are emitted from flowering rice panicles. Journal of Chemical Ecology 36: 999-1005. https://doi.org/10.1007/s10886-010-9839-6

Hodossi, S, Kovács, A., Terbe, I. (2010): Zöldségtermesztés szabadföldön. Budapest, Hungary, Mezőgazda Kiadó.

Holopainen, J. K. (2001): Blue sticky traps are more efficient for the monitoring of Lygus rugulipennis (Heteroptera, Miridae) than yellow sticky traps. Agricultural and Food Science in Finland 10: 277-284. https://doi.org/ 10.23986/afsci.5698 
Holopainen, J.K., Varis A. L. (1991): Host plants of the European tarnished plant bug Lygus rugulipennis Poppius (Het., Miridae). Journal of Applied Entomology 111: 484-498. https://doi.org/10.1111/j.1439-0418.1991.tb00351.x

Jay, C. N., Cross, J. V., Burgess, C. (2004): The relationship between populations of European tarnished plant bug (Lygus rugulipennis) and crop losses due to fruit malformation in everbearer strawberries. Crop Protection 23: 825-834.

Katona, P., Molnár, A., Nagy, A., Szanyi, Sz. (2020): The first record of Myodris annulata (Fallén, 1813) representing the second species of the family Periscelididae (Diptera: Schizophora) from Ukraine. North-Western Journal of Zoology 16(1): 98-99.

Knudsen, J. T., Eriksson, R., Gershenzon, J., Stahl, B. (2006): Diversity and distribution of floral scent. The Botanical Review 72(1): 1-120. https://doi.org/10.1663/00068101(2006)72[1:DADOFS]2.0.CO;2

Koczor, S., Vuts, J., Tóth, M. (2012): Attraction of Lygus rugulipennis and Adelphocoris lineolatus to synthetic floral odour compounds in field experiments in Hungary. Journal of Pest Science 85(2): 239-245. https://doi.org/10.1007/s10340012-0422-5

Kondorosy E. (1999): Checklist of the Hungarian bug fauna (Heteroptera). Folia Entomologica Hungarica 60: 125-152.

Kondorosy E. (2005): New true bug species in the Hungarian fauna (Heteroptera). Folia Entomologica Hungarica 66: 17-22.

Lu, Y., Wu, K., Jiang, Y., Xia, B., Li, P., Feng, H., Wyckhuys, K. A. G., Guo, Y. (2010): Mirid bug outbreaks in multiple crops correlated with wide-scale adoption of Bt cotton in China. Science 328(5982): 1151-1154. https://doi.org/10.1126/science.1187881

Marcali Zs. (2019): Poloskák jelentősége a napraforgóban. Agrofórum Online. https://agroforum.hu/szakcikkek/ novenyvedelem-szakcikkek/poloskak-jelentosege-anapraforgoban/ (29.09.2020)

McBrien, H. L., Judd, G. J. R., Borden, J. H. (1996): Potential for pheromone-based mating disruption of the mullein bug, Campylomma verbasci (Meyer) (Heteroptera: Miridae). The Canadian Entomologist 128: 1057-1064.

Miller, N. C. E. (1971): Miridae. In: Miller NCE, E. W. ed. The biology of the Heteroptera (2nd, revised edition, 1971). Middlesex, England: Classey Ltd. Hampton, 150-153.

Pansa, M., Vittone, F., Galliano, A., Tavella, L. (2008): Dynamics and control of Lygus rugulipennis Poppius in peach orchards of NW Italy. IOBC/WPRS Bulletin 37: 117-121.

R Core Team (2016): R: A language and environment for statistical computing. R Foundation for Statistical Computing, Vienna, Austria. URL https://www.R-project.org/. (10.08.2020.)

Rácz, V. (1989): Poloskák Heteroptera In: Balázs, K., és Mészáros, Z. eds. Biológiai védekezés természetes ellenségekkel. Budapest, Hungary: Mezőgazdasági Kiadó, 73-89.

Rácz, V., Bernáth, I. (1993): Dominance conditions and population dynamics of Lygus (Het., Miridae) species in Hungarian maize stands (1976-1985), as functions of climatic conditions. Journal of Applied Entomology 115: 511-518. https://doi.org/10.1111/j.1439-0418.1993.tb00421.x
Scales, A. L. (1968): Female tarnished plant bugs attract males. Journal of Economic Entomology 61: 1466-1467. https://doi.org/10.1093/jee/61.5.1466

Schaefer, C. W., Panizzi, A. R. (2000): Economic importance of Heteroptera: a general view In: Schaefer, C. W., Panizzi, A. R. eds. Heteroptera of economic importance. Boca Raton, Florida: CRC Press. 3-8.

Schuh, R. T., Slater, J. A. (1995): Preface In: True bugs of the world (Hemiptera: Heteroptera): classification and natural history. Cornell UNIVERSITY press, xi-xii.

Schwartz, M. D., Foottit, R. G. (1998): Revision of the Nearctic species of the genus Lygus Hahn, with a review of the Palaearctic species (Heteroptera: Miridae). Gainesville, FL: Associated Publishers.

Scott, W. P., Snodgrass, G. L. (2000): Response of tarnished plant bugs (Heteroptera: Miridae) to traps baited with virgin males or females. The Southwestern Entomologist 25: 101-108.

Smith, R. F., Gaul, S. O., Borden, J. H., Pierce, H. D. (1994): Evidence for a sex pheromone in the apple brown bug, Atractotomus mali (Meyer) (Heteroptera: Miridae). The Canadian Entomologist 126: 445-446. https://doi.org/10.4039/Ent126445-2

Stewart, A. J. (2002): Techniques for sampling Auchenorrhyncha in grasslands. Denisia 04. Biologiezentrum des Oberösterreichischen Landesmuseums. 176: 491-512.

Strong, F. E., Sheldahl, J. A., Hughes, P. R., Hussein, E. M. K. (1970): Reproductive biology of Lygus hesperus Knight. Hilgardia 40: 105-147.

Szanyi, Sz., Nagy, A., Molnár, A., Katona, K., Tóth, M., Varga, Z. (2017): Night-active Macroheterocera species in traps with synthetic attractants in the Velyka Dobron' Game Reserve (Ukraine, Transcarpathia). Acta Zoologica Academiae Scientarum Hungaricae 63(1): 97-114. https://doi.org/10.17109/AZH.63.1.97.2017

Tóth, M., Szarukán, I., Nagy, A., Ábri, T., Katona, V., Kőrösi, Sz., Nagy, T., Szarvas, Á., Koczor, S. (2016): An improved female-targeted semiochemical lure for the European Corn Borer Ostrinia nubilalis Hbn.. Acta Phytoptahologica et Entomologica Hungarica 51(2): 247-254. https://doi.org/ 10.1556/038.51.2016.2.9

Tóth, M., Szarukán, I., Nagy, A., Furlan, L., Benvegnu, I., Rak Cizej, M., Ábri, T., Kéki, T., Kőrösi, S., Pogonyi, A., Toshova, T., Velchev, D., Atanasova, D., Kurtulus, A., Kaydan, B.M., Signori, A. (2017): European corn borer (Ostrinia nubilalis Hbn., Lepidoptera: Crambidae): comparing the performance of a new bisexual lure with that of synthetic sex pheromone in five countries. Pest Management Science 73(12): 2504-2508. https://doi.org/10.1002/ps.4645

Tóth, M., Landolt, P., Szarukán, I., Nagy, A., Jósvai, J. K. (2019a): Improving bisexual lures for the Silver Y Moth Autographa gamma L. and related Plusiinae (Lepidoptera: Noctuidae). Acta Phytoptahologica et Entomologica Hungarica 54(1): 137-146. https://doi.org/10.1556/038.54.2019.012

Tóth, M., Furlan, L., Szarukán, I., Nagy, A., Vuts, J., Toshova, T., Velchev, D., Lohonyai, Zs., Imrei, Z. (2019b): The addition of a pheromone to a floral lure increases catches of females of the click beetle Agriotes ustulatus (Schaller) (Coleoptera: Elateridae). Journal of Chemical Ecology 45(8): 667-672. https://doi.org/10.1007/s10886-019-01087-z 
Varis, A. L. (1995): Species composition, abundance, and forecasting of Lygus bugs (Heteroptera: Miridae) on field crops in Finland. Journal of Economic Entomology 88: 855-858. https://doi.org/10.1093/jee/88.4.855

Vásárhelyi, T. (1996): Poloskák (Heteroptera) rendje In: Papp, L. ed. Zootaxonómia. Dabas, Hungary: Magyar Természettudományi Múzeum és Dabas-Jegyzet Kft. 189-195.

Wagner, E. (1952): Blindwanzen oder Miriden. Die Tierwelt Deutschlands. 41. teil. Jena, Germany, Verlag von Gustav Fischer
Witzgall, P., Kirsch, P., Cork, A. (2010): Sex pheromones and their impact on pest management. Journal of Chemical Ecology 36: 80-100. https://doi.org/10.1007/s10886-009-9737-y

Xiu, C. L., Pan, H. S., Liu, B., Luo Z. X., Williams, L., Yang, Y. Z., Lu, Y. H. (2019): Perception of and behavioral responses to host plant volatiles for three Adelphocoris species. Journal of Chemical Ecology 45: 779-788. https://doi.org/ 10.1007/s10886-019-01102-3 